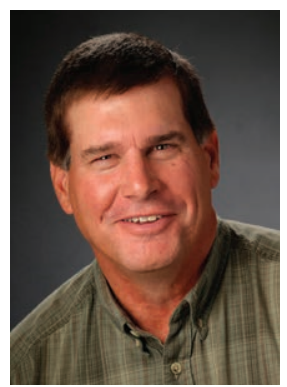

By Jeff Mosley

\title{
Browsing the Literature
}

This section reviews new publications available about the art and science of rangeland management. Personal copies of these publications can be obtained by contacting the respective publishers or senior authors (addresses shown in parentheses). Suggestions are welcomed and encouraged for items to include in future issues of Browsing the Literature. Contact Jeff Mosley, jmosley@montana.edu.

\section{Animal Ecology}

A long-term assessment of the effect of winter severity on the food habits of white-tailed deer. G. D. Delgiudice, B. A. Sampson, and J. H. Giudice. 2013. Journal of Wildlife Management 77:1664-1675. (Minnesota Dept of Natural Resources, 5463 West Broadway, Forest Lake, MN 55025, USA). In areas where white-tailed deer seek dense forest cover to avoid deep snow, habitat management should promote shrub growth adjacent to patches of dense forest.

Evaluating greater sage-grouse seasonal space use relative to leks: implications for surface use designations in sagebrush ecosystems. P. S. Coates, M. L. Casazza, E. J. Blomberg, S. C. Gardner, S. P. Espinosa, J. L. Yee, L. Wiechman, and B. J. Halstead. 2013. Journal of Wildlife Management 77:1598-1609. (US Geological Survey, 800 Business Park Dr, Suite D, Dixon, CA 95620, USA). Across all seasons of the year combined, $90 \%$ of the total area used by nonmigratory greater sage-grouse was within 3 miles of leks, and $95 \%$ of all nests were within 3 miles of leks.

Golden eagle population trends in the western United States: 1968-2010. B. A. Millsap, G. S. Zimmerman, J. R. Sauer, R. M. Nielsen, M. Otto, E. Bjerre, and R. Murphy. 2013. Journal of Wildlife Management 77:1436-1448. (US Fish and Wildlife Service, 2105 Osuna Rd NE, Albuquerque, NM 87113, USA). The golden eagle population in the western United States was stable from 1968 to 2010.

Landscape-scale features affecting small mammal assemblages on the northern Great Plains of North America. L. M. Heisler, C. M. Somers, T. I. Wellicome, and R. G. Poulin. 2013. Journal of Mammalogy 94:1059-1067. (R. Poulin, Royal Saskatchewan Museum, 2340 Albert St, Regina, SK S4P 4W7, Canada). Composition of small mammal communities in the northern Great Plains is largely determined by the combination of soil texture and precipitation regime.

Regional and seasonal patterns of nutritional condition and reproduction in elk. $R$. C. Cook, J. G. Cook, D. J. Vales, B. K. Johnson, S. M. McCorquodale, L. A. Shipley, R. A. Riggs, L. L. Irwin, S. L. Murphie, B. L. Murphie, K. A. Schoenecker, F. Geyer, P. B. Hall, R. D. Spencer, D. A. Immell, D. H. Jackson, B. L. Tiller, P. J. Miller, and L. Schmitz. 2013. Wildlife Monographs 184:1-45. (National Council for Air and Stream Improvement, 1401 Gekeler Lane, La Grande, OR 97850, USA). Adequacy of nutrition from April through 
October dictates growth and reproduction by elk more so than winter conditions. Land management planning for elk should place greater emphasis on spring-summer-fall habitat.

\section{Grazing Management}

Determining the effects of cattle grazing treatments on Yosemite toads (Anaxyrus $[=B u f o]$ canorus) in montanae meadows. S. K. McIlroy, A. J. Lind, B. H. Allen-Diaz, L. M. Roche, W. E. Frost, R. L. Grasso, and K. W. Tate. 2013. PloS ONE 8:e79263. doi: 10.1371/journal.pone.0079263. 8 p. (US Geological Survey, Forest and Rangeland Ecosystem Science Center, 970 Lusk St, Boise, ID 83706, USA). Exclusion from cattle grazing did not benefit Yosemite toads in mountain meadows of the Sierra Nevada Mountains in California.

Multi-paddock grazing on rangelands: why the perceptual dichotomy between research results and rancher experience? R. Teague, F. Provenza, U. Krueter, T. Steffens, and M. Barnes. 2013. Journal of Environmental Management 128:699-717. (Texas A\&M Univ AgriLife Research Center, PO Box 1658, Vernon, TX 76384, USA). Discusses the differences between results from grazing systems research and results reported by successful grazing managers.

Supplementation strategy during late gestation alters steer progeny health in the feedlot without affecting cow performance. J. T. Mulliniks, C. P. Mathis, S. H. Cox, and M. K. Petersen. 2013. Animal Feed Science and Technology 185:126-132. (M. Petersen, USDA Agricultural Research Service, 243 Fort Keogh Rd, Miles City, MT 59301, USA). Steer calf health in the feedlot was improved when dams received a self-fed protein supplement during late gestation while grazing dormant winter range in central New Mexico. However, net profit in the feedlot was not improved.

\section{Plant-Animal Interactions}

Disentangling herbivore impacts on Populus tremuloides: a comparison of native ungulates and cattle in Canada's aspen parkland. E. W. Bork, C. N. Carlyle, J. F. Cahill, R. E. Haddow, and R. J. Hudson. 2013. Oecologia 173:895-904. (Dept of Agriculture, Food and Nutrition Science, Univ of Alberta, Edmonton, AB T6G 2P5, Canada). Browsing by elk and physical damage by bison reduced aspen growth and reproduction more than cattle impacts. Aspen encroachment into the northern Great Plains is partially attributed to the replacement of elk and bison with cattle.

Prairie dog decline reduces the supply of ecosystem services and leads to desertification of semiarid grasslands. L. Martinez-Estevez, P. Balvanera, J. Pacheco, and G. Ceballos. 2013. PloS ONE 8:e75229. doi: 10.1371/journal. pone.0075229. 9 p. (Instituto de Ecologia, Universidad $\mathrm{Na}-$ cional Autonoma de Mexico, Apartado Postal 70-275 Ciudad Universitaria, UNAM 04510 DF, Mexico). In Chihuahuan desert grassland of northern Mexico, ecosystem health is lower where black-tailed prairie dogs have been extirpated and where mesquite has invaded. Prairie dogs positively impact groundwater recharge, soil stability, soil carbon storage, and herbage yield.

\section{Plant Ecology}

Euphorbia rayturneri (Euphorbiaceae), a new species from southwestern New Mexico, United States. V. W. Steinmann, and E. Jercinovic. 2013. Novon 22:482-485. (Instituto de Ecologia, Apartado Postal 386, Patzcuaro 61600, Michoacan, Mexico). Authors describe a new species of summer annual forb that inhabits desert grassland and propose that it be listed as Critically Endangered.

Grass-legume proportions in forage seed mixtures and effects on herbage yield and weed abundance. $M$. A. Sanderson, G. Brink, R. Stout, and L. Ruth. 2013. Agronomy Journal 105:1289-1297. (USDA Agricultural Research Service, PO Box 459, Mandan, ND 58554, USA). Experiments with four improved pasture grasses and four legumes in Pennsylvania and $\mathrm{Wisconsin}$ demonstrated that mixtures with equal proportions of species in the seed mixture (i.e., greater species evenness) did not produce more biomass nor have fewer weeds than other mixtures.

Historical fire in sagebrush landscapes of the Gunnison sage-grouse range from land-survey records. $\mathrm{B}$. E. Bukowski, and W. L. Baker. 2013. Journal of Arid Environments 98:1-9. (W. Baker, Dept of Geography, Univ of Wyoming, Laramie, WY 82071, USA). Pre-EuroAmerican settlement, dense sagebrush covered 20\%, scattered sagebrush $15 \%$, and sagebrush with scattered trees $19 \%$ of Gunnison sage-grouse range in southwestern Colorado.

Soil engineering facilitates downy brome (Bromus tectorum) growth - a case study. R. R. Blank, and T. Morgan. 2013. Invasive Plant Science and Management 6:391-400. (USDA Agricultural Research Service, 920 Valley Rd, Reno, NV 89512, USA). Results from a pilot study suggest that cheatgrass may promote its own growth by increasing the availability of soil nitrogen, phosphorus and manganese.

The biology of Canadian weeds. 152. Artemisia biennis Willd. G. O. Kegode, and S. J. Darbyshire. 2013. Canadian Journal of Plant Science 93:643-658. (Dept of Agricultural Sciences, Northwest Missouri State Univ, Maryville, MO 64468, USA). Biennial wormwood is a significant weed in the prairie provinces of Canada and the northern Great Plains of the United States. It appears to be increasing due, at least in part, to less cropland tillage. 
Woody plant encroachment facilitated by increased precipitation intensity. A. Kulmatiski, and K. H. Beard. 2013. Nature Climate Change 3:833-837. (Dept of Plants, Soils, and Climate, Utah State Univ, Logan, UT 84322, USA). Without changing the total amount of precipitation, small increases in precipitation intensity can push soil water deeper into the soil, favoring shrub and tree growth and disfavoring grass production.

\section{Rehabilitation/Restoration}

Can native annual forbs reduce Bromus tectorum biomass and indirectly facilitate establishment of a native perennial grass? E. A. Leger, E. M. Goergen, and T. Forbis de Queiroz. 2014. Journal of Arid Environments 102:9-16. (Dept of Natural Resources and Environmental Science, Univ of Nevada, Reno, NV 89512, USA). Native "weedy" forbs seeded with cheatgrass suppressed the yield and seed output of cheatgrass and possibly could serve a transitory role in plant community recovery.

Common reed (Phragmites australis) control is influenced by the timing of herbicide application. S. Z. Knezevic, R. E. Rapp, A. Datta, and S. Irmak. 2013. International Journal of Pest Management 59:224-228. (Univ of Nebraska Northeast Research and Extension Center, 57905866 Rd, Concord, NE 68728, USA). The highest level of control (92\%) was provided by imazapyr herbicide applied at either 4 or 8 ounces active ingredient per acre, applied when common reed was vegetative, flowering, or filling seed.

Effect of timing on chemical control of Dalmatian toadflax (Linaria dalmatica) in California. G. B. Kyser, and J. M. DiTomaso. 2013. Invasive Plant Science and Management 6:362-370. (Dept of Plant Sciences, Univ of California-Davis, Davis, CA 95616, USA). Aminocyclopyrachlor applied to dormant plants in fall at 4 ounces acid equivalent per acre controlled Dalmatian toadflax even when precipitation the following spring was lacking. Chlorsulfuron at the dormant stage and aminopyralid at the rosette stage were effective in wetter years.

Examination of the wind speed limit function in the Rothermel surface fire spread model. P. L. Andrews, M. G. Cruz, and R. C. Rothermel. 2013. International Journal of Wildland Fire 22:959-969. (US Forest Service, Missoula Fire Sciences Lab, 5775 W US Highway 10, Missoula, MT 59808 , USA). When calculating rate of spread in the Rothermel surface fire spread model, authors recommend that the effective midflame wind speed should be used instead of the wind speed limit currently in the model.
No long-term effects of prescribed fire on Lehmann lovegrass (Eragrostis lehmanniana)-invaded desert grassland. C. M. McGlone. 2013. Invasive Plant Science and Management 6:449-456. (Jornada Experimental Range, New Mexico State Univ, Las Cruces, NM 88003, USA). At 5 years postburn, prescribed fire did not affect the cover of any plant species or growth form in a Chihuahuan desert grassland invaded by Lehmann lovegrass.

Prescribed fire effects on resource selection by cattle in mesic sagebrush steppe. Part 1: spring grazing. P. E. Clark, J. Lee, K. Ko, R. M. Nielson, D. E. Johnson, D. C. Ganskopp, J. Chigbrow, F. B. Pierson, and S. P. Hardegree. 2014. Journal of Arid Environments 100-101:78-88. (USDA Agricultural Research Service, 800 E. Park Blvd, Suite 105, Boise, ID 83712, USA). In mountain big sagebrush habitat of southwestern Idaho, cattle selected lightly to moderately burned areas during all 5 postfire years studied.

Seedbank responses to spring and fall prescribed fire in mountain big sagebrush ecosystems of differing ecological condition at Lava Beds National Monument, California. L. M. Ellsworth, and J. B. Kauffman. 2013. Journal of Arid Environments 96:1-8. (Dept of Fisheries and Wildlife, Oregon State Univ, Corvallis, OR 97330, USA). At a site dominated by native plant species, native forbs increased 1 year following prescribed fire applied in either spring or fall. Prescribed burning did not increase native forbs on a cheatgrass-dominated site.

Weed seedling identification guide for Montana and the Northern Great Plains. H. Parkinson, J. Mangold, and F. Menalled. 2013. Montana State University Extension Bulletin EB-215. 160 p. (Extension Publications, Culbertson Hall, Montana State Univ, Bozeman, MT 59717, USA; http://store.msuextension.org). This color guide addresses seedlings and juvenile plants of 73 cropland and rangeland weed species, including 60 broadleaf and 13 grass species.

Jeff Mosley is Professor of Range Science and Extension Range Management Specialist, Dept of Animal and Range Sciences, Montana State University, Bozeman, MT 59717, USA.

Rangelands 36(1):31-33

doi: 10.2111/RANGELANDS-D-13-00080.1

(C) 2014 The Society for Range Management 